MPC MAJOR RESEARCH PAPER

\title{
The Consciousness-Raising of \#MeToo: Mobilizing Political Empathy in the Digital Age
}

By: Allana Graham

Dr. Matthew Tiessen

This Major Research Paper is submitted in partial fulfillment

of the requirements for the degree of Master of Professional Communication

Ryerson University

Toronto, Ontario Canada

August $29^{\text {th }}, 2018$ 


\section{Author's Declaration}

I hereby declare that I am the sole author of this MRP. This is a true copy of the MRP, including any required final revisions.

I authorize Ryerson University to lend this MRP to other institutions or individuals for the purpose of scholarly research I further authorize Ryerson University to reproduce this MRP by photocopying or by other means, in total or in part, at the request of other institutions or individuals for the purpose of scholarly research.

I understand that my MRP may be made electronically available to the public. 


\begin{abstract}
The lasting effect of \#MeToo's suggests that we are at a critical moment in the study of communications and media studies. This MRP will be speculative in nature, however, it is my contribution that we must move beyond literature that defends "slacktivism" and the notion that digital mediation is an impoverished form of communication (McCafferty, 2011; Baym, 2017), and instead build upon emerging frameworks that focus on the affordances of the social media age in activism theory by integrating rationality from offline, or "real life", areas of literature. In the case of \#MeToo, the personalization of politics and mobilizing structures share logic with feminism practices that predate the digital age. This indicates that perhaps an effective way to make meaning out of new and complex phenomena like \#MeToo is not diminish the human element, but rather acknowledge it as an integral part of online protest. Building on this assumption, this MRP is a commentary that considers the complexity of the events that brought \#MeToo to fruition. I will evaluate \#MeToo using emerging literature at the intersections of activism and social media, while contextualizing both the viral moment and the continued movement within feminist theory that is grounded in visceral emotions like vulnerability, anger, empathy, solidarity, and catharsis. Combining both literature that focuses on the technological and human elements should be considered in future research in order to develop theoretical frameworks that create a more holistic understanding of the cultural events that occur due to activism in the digital age.
\end{abstract}




\section{Acknowledgements}

I would first like to thank the MPC faculty for a very special year this program created a safe space for discovery and deliberation that made me eager to engage with the literature and participate in the incredibly insightful conversations that I will always look back on fondly. More specifically, I owe great thanks to my supervisor, Dr. Matthew Tiessen, for his incredible kindness and patience with me throughout the challenging process of bringing this paper to fruition. Your willingness to allow this MRP to break the mold and take a unique shape that inspired me throughout this process is a testament to your excellence as a professor. I am very grateful to have had the opportunity to work with you. I would also like to thank my second reader, Dr. Jane Griffith, for her insightful comments that strengthened my work. Lastly - to my classmates, the graduating MPC class of 2018 - I am certain that I am a better person for having spent this last year with you. I could not have achieved this without your brilliant minds, open hearts unending support. 


\section{Table of Content}

Author's Declaration.......................................... ii

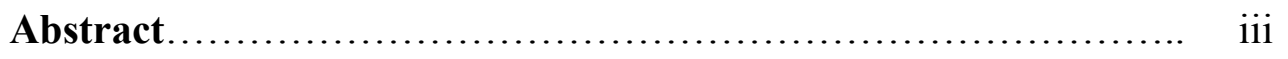

Acknowledgements.......................................... iv

Introduction.............................................. 1

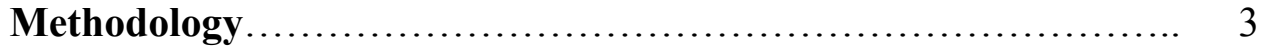

The Global Context

Setting the Stage for \#MeToo...................................... 5

The Viral Moment.............................................. 9

The Mobilization:

Social Media and the Logic of Connective Action..................... 12

The Participation

Consciousness-Raising and Hashtag Storytelling as Radical Activism....... 19

The Adoption

The Survivor Narrative, Viral Identity Politics and Political Empathy....... 26

Conclusion............................................... 31

Reference List............................................. 35

\section{List of Figures:}

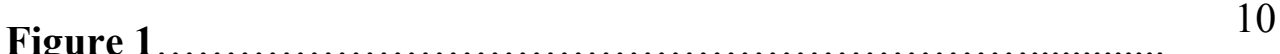

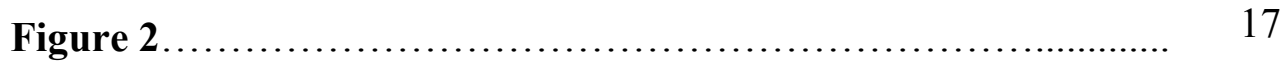

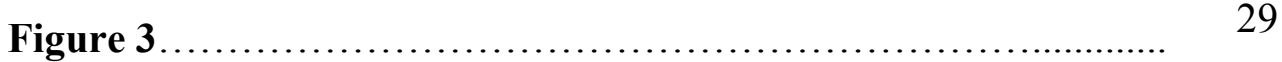


Those stories of violations we shared in quavering voices with other scared women ignited a global movement to end violence against women. We may have more formally called it "consciousness-raising”, but in essence we were telling each other stories to reclaim ourselves and our humanity.

We created a feminist culture with these stories, not through narratives of logic and structure, but by creating verbal snapshots of the lived experiences of women.

We didn't have to tell the same story in order to resonate with each other. Each story was unique, but the act of telling our stories created strong bonds among diverse women who worked together to change our realities. Each story generated echoes of experiences we could all relate to our lives.

We would imagine a world in which women lived in freedom from violence....

Loretta J. Ross

Telling Stories to Change the World (2008) 


\section{Introduction}

Since 1927, Time magazine has been naming a Person of the Year. With each annual publication of the feature, the magazine highlights a person, idea, group or object that "for better or for worse... has done the most to influence the events of the year" (Time, 2002). Since the creation of social media and its near ubiquitous adoption, the publication has chosen a few thought-provoking symbols related to its use and integration into our behaviour. For example, in 2006 the Time person of the year was You. The rationality behind the decision was grounded in the proliferation of user-generated content on the "world wide web" at the time: the early co-creation of Wikipedia pages, the video uploads to a new platform called YouTube, the sharing of photo albums on Facebook, etc. Ordinary individuals were being empowered by new technology that allowed them to explore novel ways of self-identifying by sharing their own perspectives and having unprecedented access to large online communities. In 2012, the magazine opted for a contentious person of the year: The Protester. From the Arab Spring in Tahrir Square, to the camps of the Occupy Wall Street movement in the United States and elsewhere, to the indignados in Spain, the year would be remembered for its development in activism as it embraced a new mobilizing tactic that leveraged the affordances of a social media age.

In retrospect, the decision to highlight these topics almost seems to foreshadow what has since transpired as social media and politics have, in recent years, become increasingly intertwined. Time's recent persons of the year reflect the gradual cultural shift towards the personalization of politics and the changing patterns of political participation following the adoption of social media as an accepted method of engaging in protest. With this in mind, it 
should not have come as a surprise that in 2017, the magazine declared The Silence Breakers the person of the year. The title referred to the group of women who sparked a social media facilitated global movement that would force us to collectively re-evaluate our understanding of the female experience in the continued fight for gender equality. Academics and pundits alike continue to debate, and often negate, the effectiveness of digital activism as a means for bringing lasting social or political change. Yet in a single tweet, the hashtag \#MeToo created meaningful discourse about sexual violence and harassment against women. The success of the hashtag \#MeToo has brought visibility to survivors of sexual violence and harassment, and the movement continues to be impactful across all ages, classes, industries and continents.

The lasting effect of \#MeToo suggests that we are at a critical moment in the study of communications and media studies. This MRP will be speculative in nature, however, it is my contribution that we must move beyond literature that defends "slacktivism" and the notion that digital mediation is an impoverished form of communication (McCafferty, 2011; Baym, 2017). Instead, we should build upon emerging frameworks that focus on the affordances, or perceived action possibilities (Norman, 2013), of the social media age in activism theory by incorporating insight from offline, or "real life", areas of literature. In the case of \#MeToo, the personalization of politics and mobilizing practices mirror feminist theory that predates the digital age. This indicates that perhaps the most effective way to make meaning out of new and complex phenomena like \#MeToo is to not diminish the human element, but rather acknowledge it as an integral part of protest, whether it occurs online or offline.

Further, I would attest that any analysis of \#MeToo that upholds the deterministic viewpoint that preserves a strict distinction between online and offline, in the sense that 
protest is not impactful until it occurs in real life, diminishes not only the global context, but most importantly, the emotional labour of sharing traumatic experiences, regardless of the forum. I would stress that as we continue to develop ways of understanding political participation in the digital age, it is negligent to maintain that engaging in online discourse is anything less than an extremely important part of how we learn from and with each other, construct our realities, and develop an understanding of our place in society.

In order to explore this perspective, I will evaluate \#MeToo using emerging literature at the intersections of activism and social media, while contextualizing both the viral moment and the continued movement within feminist practices that are grounded in visceral emotions like vulnerability, anger, empathy, solidarity, and catharsis. I believe that combining both literature that focuses on the technological and human elements create a more holistic understanding of the event. Goodwin \& Jasper (2003) argue that social movements are created by a range of variables that coincide to bring them to fruition. Building on this assumption, this MRP is a commentary that considers the complexity of the events that brought \#MeToo to fruition. In the sections to follow, the variables that I will consider are: 1) the global context of feminism in the years leading up to 2017;2) Twitter as a place for mobilizing action networks, 3) storytelling in the digital age as a modern conception of consciousness-raising; and 4) the survivor narrative and the role of empathy in the adoption a social movement's messaging.

\section{Methodology}

This MRP provides critical insight to the emergence, adoption and success of \#MeToo as a viral moment and lasting movement. It will both lean on and contribute to a variety of 
developing literature at the intersections of feminism and activism in the digital age. I considered literature focused on topics ranging from social movement theory, to activism, political participation, feminism, actor network theory, identity politics, social psychology, framing theory and beyond.

Throughout this process, I discovered that \#MeToo is simultaneously representative of a new phenomenon in the digital age, while maintaining very familiar logic from feminist practices that predate social media. This considered, scholars developing theory for the former claim that these frameworks are still emerging and require further research, and the traditional understandings of framing and mobilizing processes of the latter are outdated or even increasingly obsolete as they related to the rapid co-creative nature of hashtag activism. I determined that no single framework would effectively address the critical elements in isolation, but rather components from both are needed to contextualize \#MeToo's viral moment. With that in mind, this MRP will be very speculative in nature; it takes a multidisciplinary approach that engages with literature at the intersections of communications and media, feminism and social psychology in conjunction in order to explore how together they bring logic to the complexity of emerging social movements in the digital age. This MRP is a qualitative critical content analysis that considers both popular (such as traditional news and magazines) and academic sources in order to include the most current information available, while also more broadly contextualizing the \#MeToo phenomenon. 
Throughout the paper, there will be small samples of tweets. These tweets were collected using Sysomos, and the search was refined by:

- Keyword (must include): "\#metoo",

- Keyword (must exclude): "RT",

- Platform: Twitter,

- Date: Oct. $15^{\text {th }}$.

These parameters ensure that that the search only collected tweets that included the hashtag, avoided retweets to remove redundancy, and were posted within the first 24 hours after the call to action, while \#MeToo was it peak virality. They have not been gathered for the purpose of critical analysis, but rather as examples of engagement with the hashtag. Due to the sensitive nature of the tweets and the fundamental theme of consent that is at the core of the \#MeToo movement, I have chosen to exclude the users' Twitter handles (usernames) to maintain anonymity of the participants.

In order to derive meaning from \#MeToo as it transpired (and as it continues to unfold), I have established 3 distinct elements that will be explored: 1) the mobilization, 2) the participation, and 3) the adoption. As a prelude to the analysis, I begin with establishing a global context by placing \#MeToo along a timeline of events, both online and offline, that catalyzed one another and built international momentum.

\section{The Global Context:}

\section{Setting the Stage for \#MeToo}

Before the analyzing \#MeToo through the lens of the technological affordances that mediated its global reach, I believe it is imperative to reflect on the circumstances leading up 
to \#MeToo as we speculate why the masses were ready and willing to participate, and the media was ready to listen. Existing global feminist movements, the normalization of the hashtag as effective protest, cultural moments like the Women's March, and the volatile nature of the political climate of 2016 in the era of Donald Trump, all contribute to a confluence of factors that together contributed to the events that followed.

In recent years, feminist movements around the world have achieved momentous victories on issues like voting rights, sexual and reproductive health, freedom of expression, marital rights, access to opportunity and education, and overall gender equity under the law. Though there are still a wide range of human rights issues worthy of continued attention, one could presume that given recent successes, feminists around the world were entitled to have a sense of optimism at the prospects for social change. In a networked world, one that affords immediate access to events as they transpire, women around the globe celebrate the win of one woman as a win for all women - inspiring action and hope. It is important to contextualize \#MeToo within a global landscape in order to understand the waves of momentum that contributed to its virality on the global stage.

Feminism today finds multiple forms of expression across cultures and contexts. Consider India, where in 2013, the federal court introduced long-fought amendments for offences like acid attack, sexual harassment, voyeurism, stalking to the Indian Penal Code (Borpatragohain, 2013). In Lebanon, Tunisia and Jordan, courts repealed archaic laws that allowed rapists to avoid criminal prosecution by marrying their victims (Grant, 2018). Despite being a historically non-secular nation, a constitutional referendum in the Republic of Ireland extended civil marriage rights to same-sex couples, becoming the first country in history to do so by popular vote (Johnston, 2015). Ireland has since held another referendum that brought 
expats from around the world back to their homeland to vote on the issue of access to safe and affordable abortions, resulting in a landslide victory in favour of a women's right to choose (McDonald \& Graham-Harrisson, 2018). In Canada, our most recent federal election voted in a majority government at the leadership of Justin Trudeau, a self-identified feminist who appointed the nation's first gender-balanced cabinet "because it's 2015" (Ditchburn, 2015)

Though it is important to note that women's rights advocates are not a homogenous group, especially when considering the global context of feminism today, the notion of progress seemed, though slow and complex, feasible. For all its flaws and complications in execution, the topic of violence against women as a human rights issue had, at the very least, emerged as a pressing issue on the global agenda (Miller, 2004; Zwingel, 2012). Indeed, the juxtaposition of this careful optimism with the results of America's most recent federal election rallied waves of resistance. Despite criticisms of her candidacy, the possibility of the election of Hilary Clinton as the first ever female President of the United States would represent a victorious moment for feminism around the world, if only symbolically. From a feminist perspective, the election of Donald Trump was, in many ways, representative of a regression for social issues in America, with a ripple affect crossing international boarders. His platform was and continues to be deeply divisive; throughout his campaign, he capitalized on populist, "un-presidential" messaging that, from a liberal perspective, was decidedly offensive. From mocking a disabled reporter, to calling Mexicans drug dealers and rapists, to perpetuating the narrative that all Muslims are terrorists, to considering punishment for women who have abortions, not to mention the Access Hollywood tape that was leaked only one week before the election, the controversial era of Donald Trump expanded political discourse to those who may not have otherwise considered themselves interested in politics, 
let alone activists.

Social media has played a significant role in introducing the masses to politicized discourse in North America. The hashtag has been leveraged and normalized as an effective way of streamlining conversations, protests and communities (Papacharissi, 2010; Bennett \& Segerberg, 2012; Clark, 2016). Most obviously, throughout his candidacy and into his presidency, Donald Trump himself has chosen Twitter as his favourite means of communicating with the public, capitalizing on a "call out culture" that will further be explored in the section to follow. Within hours of the announcement of Donald Trump's victory, \#NotMyPresident became the top trending topic on Twitter. The hashtag reflected the masses who strongly disapproved of the results of the election, building an online community of resistance. The hashtag acted as a unifier to create an unofficial coalition of already mobilized activist organizations like \#BlackLivesMatter and Antifa, as well as communities like the LGBTQ+, and those advocating for immigrant rights, the Muslim community, worker's rights and gun control, etc. Facebook pages named "Trump Is Not My President" were created, quickly organizing protests to display their opposition offline. The following day, large protests were held in nearly 40 cities across the United States (Taylor, 2016). \#BlackLivesMatter, a global network and human rights movement organized in response to anti-Black racism ("Black Lives Matter," n.d.), is deserving of credit for playing an instrumental role in the adoption of social media as an effective tool for bringing visibility to injustices. Their community has leveraged social media by utilizing features such as live streaming to document moments of discrimination and violence, Facebook pages to mobilize in-person demonstrations, and hashtags to move their engagement from the margins to the masses. These topics will be further explored in sections to follow. 
The rising momentum of the \#NotMyPresident hashtag translated into \#WomansMarch, a women-led movement "providing intersectional education on a diverse range of issues and creating entry points for new grassroots activists" (Women's March", n.d.). The origins of this movement began with the organizing of The Women's March on Washington, intended to be a single protest in response to the inauguration of Donald Trump. The movement, organized online, instead inspired crowds of women and allies in hundreds of major cities on every continent around the world, increasing the visibility of feminist activism globally and qualifying it as the largest and most peaceful protest day in history (Broomfield, 2017).

These events set in motion the mobilization of growing protest communities that adopted new forms of political participation both online and offline. Indeed, I would argue that it is also negligent to maintain the argument that there is definitive distinction between online and offline identities and political participation. That is, we must consider that online engagement today has become an extension of the human experience, and a legitimate and effective form of human expression.

Though the term "me too" came into collective consciousness seemingly overnight, the campaign dates back to 2006. Tyrana Burke, an African American human rights activist, coined "me too" and launched a movement to inspire "empowerment through empathy" to "help survivors of sexual violence, particularly young women of colour from low wealth communities, find pathways to healing" ("Me Too Movement," n.d.). Though the masses may have not been privy to the movement as the hashtag began to trend on social media, it is important to recognize its origins in black feminist activism and significant that the original intention remained consistent as the hashtag went viral. 


\section{The Viral Moment}

In the early days of October 2017, actress Ashley Judd accused Oscar-winning producer and Hollywood elite Harvey Weinstein of sexual misconduct. Her courage to break the story and share her own experience of coercion and harassment inspired dozens of other leading women to follow suit and validate her claims with their own similar stories, leading to an unraveling of the media mogul's reputation and career in the weeks to follow. Witnessing a growing stream of women alleging violations that range from harassment to rape, Alyssa Milano took to Twitter to express her solidarity and to engage her community of followers in the conversation. She tweeted, "If all women who have been sexually harassed or assaulted wrote 'me too' as a status, we might give people a sense of the magnitude of the problem" (Milano, 2017). This single tweet encouraged women, and some men, to engage in a global conversation about sexual violence and harassment.

According to Twitter, the hashtag \#MeToo was used nearly 1 million times within 48 hours of Milano's call to action. The hashtag trended globally, being translated into 5 languages, and across 85 countries (Park, 2017). Figure 1 details a CNN report that demonstrates \#MeToo's global reach: 


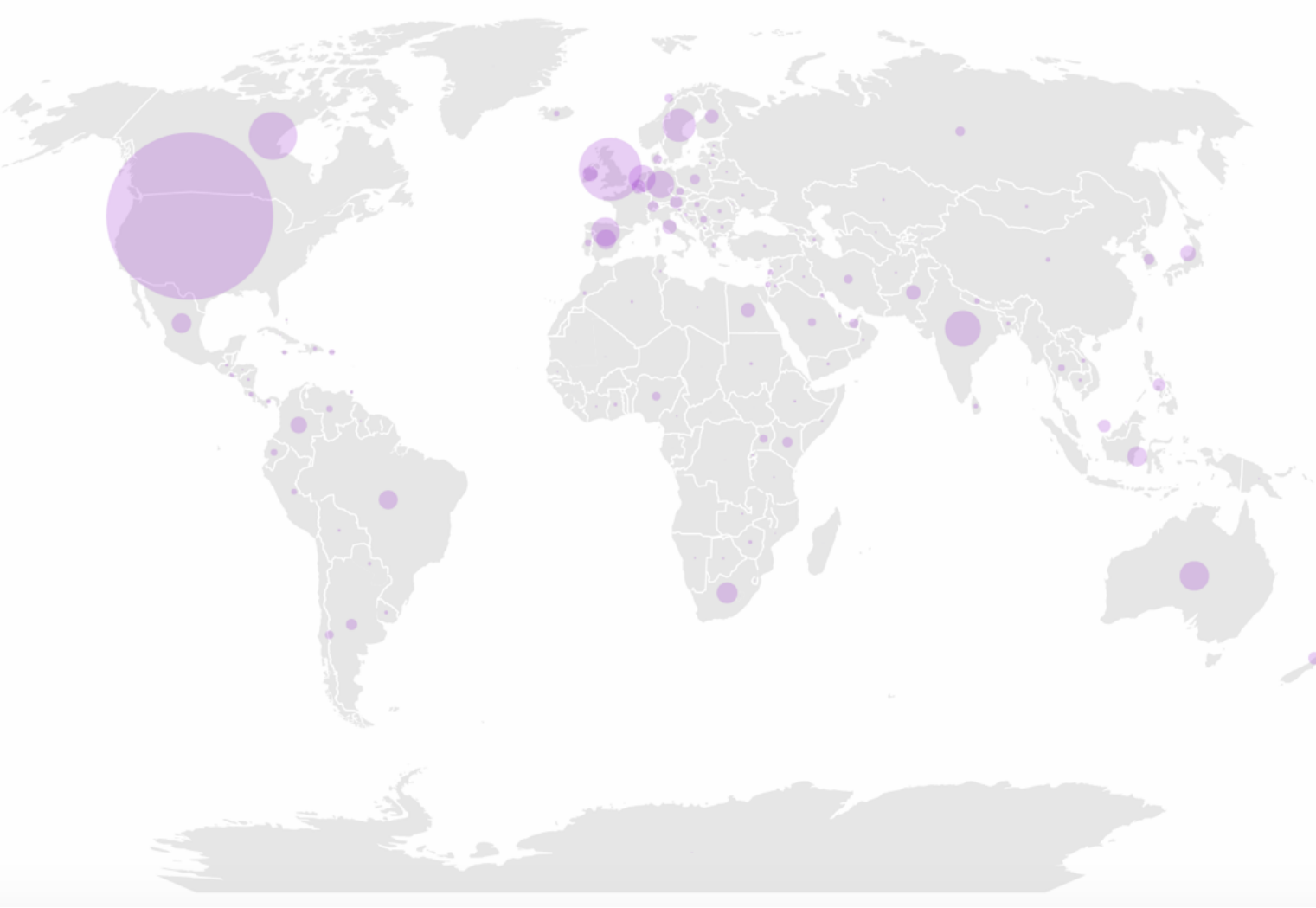

Figure 1. The circle size represents total Facebook, Instagram, and Twitter posts containing the exact phrase \#MeToo. Adapted from “\#MeToo's global moment: the anatomy of a viral campaign," by Fox, K., \& Diehm, J, 2017. CNN. Retrieved from https://www.cnn.com/2017/11/09/world/metoo-hashtag-global-movement/index.html

On Facebook, there were nearly 12 million posts, comments and reactions that had engaged with the hashtag \#MeToo by 4.7 million users around the world. Facebook's analysis of engagement within those 48 hours suggested that $47 \%$ of all users in the United States have a friend that posted \#MeToo ("More than 12M 'Me Too' Posts," 2017).

Engagement with the hashtag brought to the surface a wide variety of perspectives on the topic of sexual violence and harassment against women. \#MeToo offered counternarratives to the hegemonic stance often perpetuated by the media that problematized the victim and diminished the responsibility of the predator. Notable themes within the tweets 
range from expressions of gratitude and solidarity, to highlighting the emotional labour of sharing trauma, to reframing the blame of abusive situations, and most frequently and importantly, to personal stories of sexual harassment and violence. The virality of \#MeToo drove the conversation from the margins to the mainstream, and along with it the voices and stories of individual participants. This forced traditional media, and beyond, to engage with a counter-narrative and renegotiate the boundaries as it pertains to women's bodies, harassment, consent, and violence.

\section{The Mobilization:}

\section{Feminism in the Digital Age, Social Media and The Logic of Connective Action}

In many ways, \#MeToo represents an unprecedented moment not only for mass mobilization and highly visible protest in the age of social media, but also for new forms of listening on a global scale. From the perspective of technological affordances, it is emblematic of a noticeable cultural pivot: unlike previous moments of digital activism, the success of \#MeToo occurred without any need for in-person demonstration of "fact" or evidence. This to say, without a mass protest or event in "real life", \#MeToo successfully ignited a conversation on and offline by raising awareness of a latent social issue. This suggests that perhaps we must reconsider how we define legitimate forms of activism in the digital age, and by extension, that we continue to think critically about current assumptions as we build upon the growing body literature that helps us make sense of the political action. On the other side of this same coin, many aspects of \#MeToo are not new at all, but rather are rooted in feminist practices that can be linked as far back as the uprising of the Women's Liberation Movement and the progress of later waves of feminism and their teachings. I will 
evaluate these two outlooks in conjunction in order to examine how this viral protest moment came to fruition.

Critical to the mobilizing logic of \#MeToo are organizing strategies for building collective identity and affecting change that date back to the political foment of the 1960s. Following the first wave of suffragists who achieved immense progress for gender equality by winning the right to vote, second-wave feminists sought to address the crisis that loomed silently in the personal lives of women who existed in a culture that deemed private matters of the home too taboo to discuss in the public sphere (Munro, 2013). In her seminal book The Feminine Mystique, Betty Freidan (1963) coined the phrase "the problem that has no name" to detail the prevalence of an overwhelming feeling of dissatisfaction and a strong yearning for a life beyond the domestic duties of the housewife in the United States. Suburban wives struggled with this reality in isolation, contending with the feeling that she was alone in feeling unchallenged, unvalued and unseen beyond homemaking and childrearing. In order to address this silent phenomenon, women engaged in what was formally called "consciousness raising circles", where they would gather in small group conversations to air their grievances and build community (Plott \& Umansky, 2000). The intention of these gatherings were to free women from the idea that their unhappiness was not a product of individual experiences and emotions, but rather the product of a larger set of factors that prevented equal participation of genders across all aspects of society.

This was achieved through story telling, where each woman had the opportunity to articulate their unique experience in a safe space, allowing them the chance to intentionally reconstruct a relationship with their identities, emotions and gender. The rationality behind this process attests that "the personal is political", a once radical hypothesis that suggests that 
bringing visibility to diverse experiences inspires empathy, validates the emotions of the individual, and shifts public perception of marginalized populations.

The practices established in this era are still at the foundation of feminism today however, second-wave feminist literature has been comprehensively criticized for its narrow view of the female experience of the time. The argument is that histories of feminist progress in the 1960s neglect the deeply connected relationship between the women's suffrage movement and the civil rights movement, diminishing the contributions of feminists of colour who suffered multiple layers of oppression. A third wave of feminism emerged that included a wider variety of perspectives on the female experience, challenging the notion of gender as a homogenous or binary experience (Munro, 2013). Crenshaw (1989) introduced the theory of intersectionality to feminist thought, creating frameworks of analysis to understand the manifestations of identity politics in movements that question the intersections among gender and most predominantly race, class, religions, sexuality, among many other defining qualities within the spectrum of self-identification (Crenshaw, 1989; Whittier, 2017).

Sowards and Regenar (2009) explore the role of discursive activism in the rhetorical practice of consciousness-raising and how it has transformed into its current function in the "third-wave". They argue that its modern conception "instills a critical perspective that focuses on personal and social injustices" (Sowards \& Regenar, 2009, p. 535), and that this in turn affects discourse about gender inequalities throughout the public sphere. Clark (2014) compares the feminist presence online to the practice of consciousnessraising circles, recognizing that discursive activism has always been very important for progressive feminist politics. The digital era is privileged with access to social media and mobile technologies that allows for the participation of marginalized voices(Clark, 2014), 
potentially creating a diverse range of spaces to engage in dialogues that challenge hegemonic ideologies (Dixon, 2014).

The technological affordances of the globalized world and the adoption of social media have enabled what some feminist media scholars identify as a budding fourth-wave: an emerging era of "call-out" culture that focuses on micro-politics in everyday rhetoric and practices as well as hegemonic oppressive cultural narratives (Munro, 2013). This observation parallels Lance Bennet's research which makes an influential contribution to the intersections of political participation and group-based identity politics in the age of social media. Bennet (2012) proposes a framework for understanding large-scale collective action that is mediated through social media and driven by personalized action frames. He asserts that there has been a behavioural shift towards the personalization of politics due to increased access to technology and thus a diminishing loyalty to formally organized institutions like political parties, religions, unions, etc. He suggests that new social movements "often include a multitude of issues brought into the same protests through a widely shared late modern ethos of diversity and inclusiveness" (Bennet, 2012). The identity politics that developed out of the suffragist and civil rights movements concentrated on the collective action of a group identity (women, racial minorities, immigrants, etc) or causes (segregation, voting rights, anti-war, etc). These logics have since developed into more heterogeneous collective action networks that allow for the participation of many perspectives, and therefore a diversity of participants with intersectional identities. He hypothesizes that "the more diverse the mobilization, the more personalized the expressions... involving communication technologies that allow individuals to activate their loosely tied social networks" (Bennet, 2012, p.21).

Bennet and Segerberg (2012) introduce the logic of connective action, an emerging 
framework that expands upon the understanding of collective action in relation to digital activism. Reinforcing Milan's (2014) assertion that the politics of visibility creates an understanding of "individuals-in-the-group", Bennett and Segerberg (2012) define a connective action network by its personalized content sharing across social media networks within an online community that shares a collective identity, despite the existence of explicit coordinators. Parallel to the second-wave phrase "the personal is political" (Plott \& Umansky, 2000), Bennet and Segerberg (2012) assert that the technological affordances of social media allow users to share personal experiences and this plays a pivotal role in the virality and, by extension, visibility of online activism. The most defining characteristic of the logic of connective action is the personal action frame: a call to action that is "inclusive of different personal reasons for contesting a situation that needs to be changed" (Bennet \& Segerberg, p. $745,2012)$.

Bennet \& Segerberg (2012) offer three frameworks of analysis for the development of action networks in the digital age, depicted in the figure below: a traditional collective action model (right), a hybrid connective action model (centre), and an emerging connective action model (left). Figure 2 depicts the distinguishing elements of collective and connective action frameworks: 


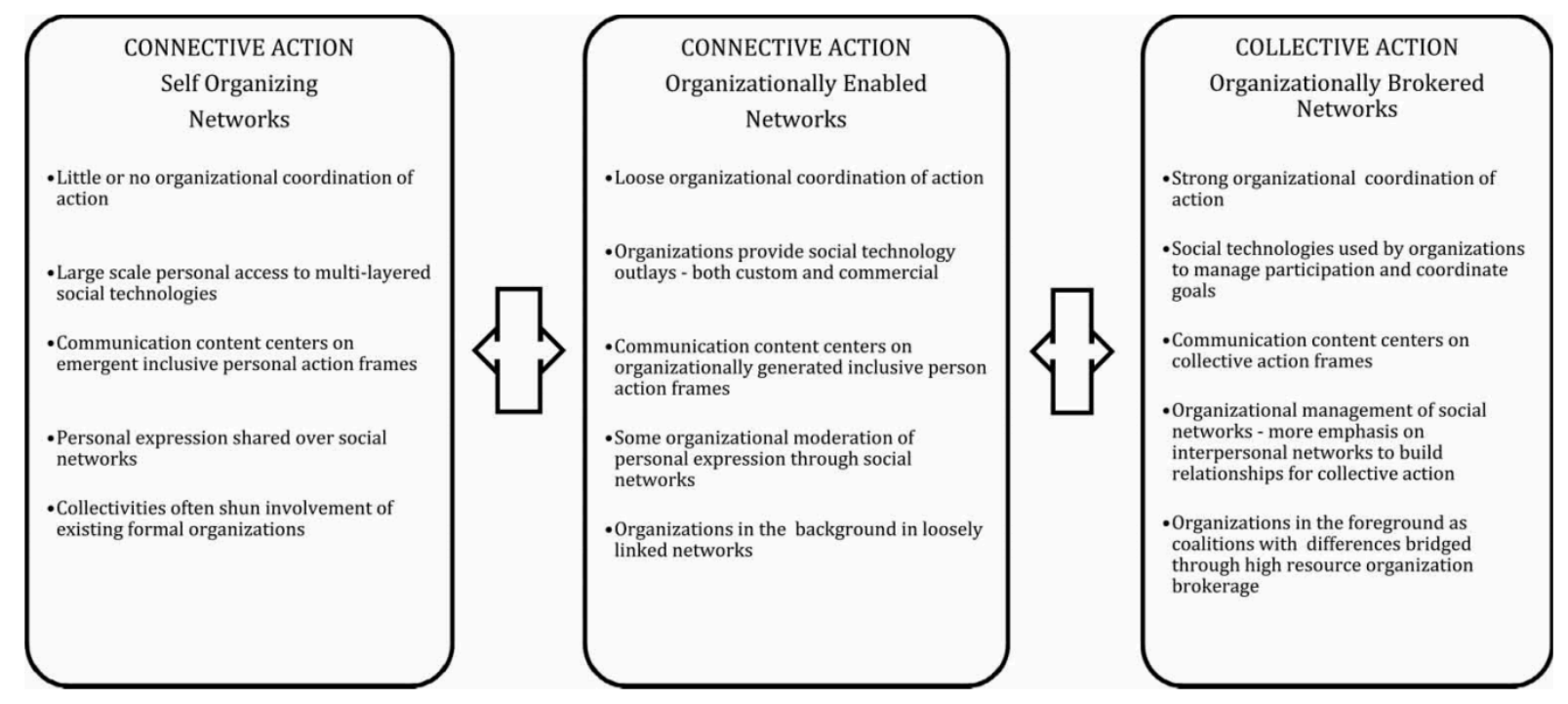

Figure 2. The defining qualities of collective and connective action frameworks. Adapted from "The Logic of Connective Action" by Segerberg, A. and W.L Bennet, 2012.

Communication \& Society, 15(5), 739-768. https://doi.org/10.1080/1369118X.2012.670661

These frameworks are helpful for understanding the viral \#MeToo moment. The formation of the social movement occurred out of a protest logic that did not maintain any of the traditional collective action elements of an organizationally brokered network. Further, the hybrid network assumes that engagement centers on loose organizational ties and thus an intentionally created inclusive action frame, features that were not afforded to the rapid cocreation of the themes of the conversation. \#MeToo, then, fits quite neatly into the logic of connective action, the framework that assumes action occurs across several social networks, driven by the highly personal, where participants have little or no relationship to one another. Bennet \& Segerberg (2012) describe this connective logic as follows:

taking public action or contributing to a common good becomes an act of personal expression and recognition or self-validation achieved by sharing ideas and actions in trusted relationships. Sometimes the people in these exchanges may be on the other side of the world, but they do not require a club, a party, or a shared ideological frame 
to make the connection. In place of the initial collective action problem of getting the individual to contribute, the starting point of connective action is the self-motivated (though not necessarily self-centered) sharing of already internalized or personalized ideas, plans, images, and resources with networks of others.

In the case of \#MeToo, the hashtag behaved as an easily personalized call to action frame, one that allowed each participant to contribute to a growing community of discourse comprised of (predominantly) women around the world. One could assume that, as Bennet and Segrerberg (2010) would describe, the act of engaging with the hashtag indeed may have been self-motivated, it may not have been entirely a self-centered act. With each tweet, participants validate their own experience of harassment and/or violence, while also validating the experiences of all women in a rare moment of public-facing and highly visible vulnerability, solidarity and trust. Among the many elements that make connective action unique from established understandings of protest logic, perhaps the most novel is the essential role of sharing: "the personalization that leads actions and content to be distributed widely across social networks" (Bennett \& Segerberg, 2012). The affordances of new communication technologies enable rapid expansion and therefore increased visibility of personal political issues.

However insightful, Bennett \& Segerberg themselves note that connective action is incomplete in its ability to meaningfully assess the sustainability and effectiveness of activism. I would suggest that part of the reason action network scholars struggle to develop comprehensive frameworks that would address this gap is due to the working definitions of what "effective" activism is in the digital age. There is still a sense that in order for a protest to be effective, it must mobilize the masses for in-person demonstration. I believe that lasting change rarely occurs in this fashion - rather, it takes meaningful discourse to renegotiate our 
norms, and bringing awareness to issues in society triggers this process. I would suggest that there is a need for further research on alternatives to in real life activism, research that focuses on emerging forms of discursive activism that allows for individual actors to contribute to changing our understanding of the world and of ourselves.

\section{The Participation:}

\section{Consciousness-Raising: Hashtag Storytelling as Radical Activism}

What does it mean to have thousands of voices join a digitally-mediated conversation, driven by a personal investment in an issue or cause? Each participant chooses to shout one deeply personal experience or perspective that echoes those of many others. Despite their similarities, all are unique. Do we call this protest? Beyond this, why did these individual actors choose to engage? These questions are at the centre of understanding \#MeToo.

I think it is also worth considering that in the case of \#MeToo, there is a percentage of women who engaged with the hashtag that may not have understood that they were participating in what would later be recognized as an extremely effective protest. Further, I would also suggest that there is a portion of women who would not consider themselves activists, let alone feminist activists. They do, however, identify as women who have experienced sexual violence and/or harassment, and therefore they entered the conversation not from a place of loyalty to a cause or institution, but rather from deeply personal motivations including personal empowerment or an expression of solidarity. It is interesting to find, in retrospect, that this online behavior - whether intentional or not - shared the effects of traditional protests or activism.

This is not the first time that a hashtag was leveraged as a virtual meeting place for 
contentious discourse, nor was it the first time it has occurred to address a feminist protest moment. Though academic literature surrounding Twitter continues to evolve, activist and feminist scholars have recognized the growing trend and have adopted the term "hashtag activism" when addressing this behaviour (Gunn, 2015; Yang, 2016; Clark, 2016; Shaw, 2012). The hashtag \#MeToo followed in the footsteps of online protest moments like \#WhyIStayed, \#RapeCultureIsWhen, \#EverydaySexism, \#Ferguson, \#BlackLivesMatter, and \#SolidarityIsForWhiteWomen, to name a few, and they have helped to normalize these online activities as new and highly visible - and effective - forms of feminist protest.

Historically, feminist protest relied heavily on the collective voice, where the power of a movement was related to masses of people using the same language to drive a narrative (Plot \& Umansky, 2000). However, with the shift to protests taking place in the digital space, Gerbaudo (2014) argues that it is important to recognize the relationship between the collective and the individual. Gerbaudo and Treré (2015) suggest that social media activism is often studied to understand how to organize "boots on the ground" protests, but the importance of collective identity building is greatly neglected. Their research explores this gap, highlighting the processes of collective identity building as reflective of "technological affordances of social media, the cultural values associated with their use and the prevailing forms of social experience in the digital era" (Gerbaudo \& Treré, 2015). Milan (2014) notes that social media plays a role in modern identity creation: (1) it amplifies the "interactive and shared" elements of collective identity, and (2) it sets in motion the politics of visibility, which is defined as "a process which creates individuals-in-the-group, whereby the 'collective' is experienced through the 'individual' and the group is the means of collective action, rather than its end" (Milan, 2014, p.887). This process highlights the importance of 
discourse in and of itself as a vital component to the success of identity building and, ultimately, the success of the larger online discourses that emerge from within these onlinecommunities.

Twitter introduced the concept of the hashtag. The micro-blogging social media platform established this behaviour by connecting the pound symbol (\#) to a filtering system that connects content related to a topic. As a topic gains popularity, it begins to "trend", creating a highly visible and easily digestible stream of tweets. Hashtag activism occurs when "large numbers of postings appear on social media under a common hashtagged word, phrase or sentence with a social or political claim" (Yang, 2016, p. 13). The term "hashtag feminism" has been extended to feminist activism that occurs online, primarily on Twitter, and it has become a powerful tool for creating and engaging in discursive action which aims to challenge systems of gender inequality around the world (Clark, 2016). This rationality has been greatly leveraged by women of colour, for example, who have utilized the platform in order to share their lived experiences, moving their voices from the margins and into dominant discourse about women in contemporary culture (Gunn, 2015).

While exploring the significance of hashtag activism during \#WhyIStayed, the 2014 outcry against domestic violence, Clark's (2016) work leans on a theme introduced in previous sections: feminism has always had strong roots in discourse as an activism strategy, and the digital era has only magnified its potential. Despite this, digitally mediated discourse is often still regarded as simply a channel for mobilizing online communities in order to organize "meaningful" acts of protest and offline demonstrations. There is a gap in scholarship related to feminist activism online which should regard digitally mediated discourse as an act of protest in and of itself, not simply a stepping stone to offline 
demonstrations. While feminist studies take discursive action seriously, this is not yet diligently applied to online activism (Clark, 2016; Shaw, 2012).

Gunn (2015)'s work is some of the earliest to examine the affordances of Twitter, specifically its relationship to feminist activism, including the rise of Black Twitter. Her work connects the ability to express personal experiences through a tweet to the feminist notion of "the personal is political", and the subsequent conversations that are created related to consciousness-raising practices that were critical to the success of the Women's Liberation Movement. The concept of consciousness-raising has been and continues to be a controversial idea to those outside of feminist scholarship; the act of engaging in discourse is often relegated to a form of personal therapy, neglecting its function in building community and collective awareness. On the other side of this debate, advocates of consciousness-raising agree that the practice is therapeutic in nature, but also that there is a radical and political motivation for sharing personal experiences in order to challenge oppressive structures (Gunn, 2015). In a text transcribed from her speech held at the National Women's Liberation Conference held in Chicago 1968, Kathie Sarachild defined radicalism in activism as the desire to seek the true roots of problems, and the practice of consciousness-raising as "studying the whole gamut of women's lives" in order to better the lives of all women through personal emotional work (Gunn, 2015).

The process of sharing personal experiences, critiques, and reflections online creates a collective reality that Gunn (2015) has called "lived experience tweets". Where historically the process of engaging in a protest would involve the use of shared language and a collective expression, one of the greatest affordances of Twitter as a platform is the ability to maintain one's own personal voice while participating in a collective online activism. Consider an 
offline demonstration, amassing in similar numbers to those who engaged with \#MeToo. If each woman was to shout her own personal reason for attending, her voice would be lost in the chaos. It is for this reason that when traditional protests like marches take place, repetitious chants or slogans must be used to both rally participants and express collective, rather than individual, views. Twitter, as a streamlined microblogging platform, instead, allows for each unique voice to be maintained and easily consumed by followers of the online conversation in a way that, at once, combines personal experiences with the power of mass demonstration. The ability to not only clearly state your relationship to the cause, but also the possibility to have it effectively heard is a unique privilege of our digital era.

The mass engagement with \#MeToo suggests that, following Gunn (2015), \#MeToo was a digital manifestation of "the problem that has no name", reflecting the persisting silencing that plagues female experience. In the case of \#MeToo, many of tweets mirrored emotions that women harbored in mid-century America: shame, isolation, guilt, fear, etc. However, unlike the consciousness-raising that would have occurred in quiet social hubs, social media has created global networks that give visibility to participants at low cost and unprecedented speed. Many who engaged with \#MeToo owned their experiences by using the first person to share their deeply personal stories of violence, harassment and fear. Below are a few examples of the hundreds of tweets in the sample collected that use the first person to take ownership and share their experience:

\section{\#MeToo}

And I was blamed for it.

I was told not to talk about it. I was told that it wasn't that bad.

I was told to get over it. 8:07 PM - Oct 15, 2017 
Being raped once made it easier to be raped again. I instinctually shut down. My body remembered, so it protected me.

I disappeared. \#metoo 11:53 PM - Oct 15, 2017

I've lost count of how many times I've lied and told a guy I have a boyfriend because he wouldn't take a simple "no" for an answer \#MeToo 2:35 PM - Oct 16, 2017

\#MeToo

Bosses, friends, boyfriends, strangers. All "good guys."

I've been assaulted by "good guys." 5:59 PM - Oct 15, 2017

\#MeToo When I served in the military. More than a few times. I stayed silent for self preservation. I regret it daily. 5:52 PM - Oct 15, 2017

At the age of 17, a date with a 23 yr old, changed my life forever...\#MeToo" 1:02 PM - Oct 15,2017

Each tweet is a brief snapshot of a real person's story, compelling those witnessing the hashtag unfold to address a reality that Alyssa Milano described as providing "a sense of the magnitude of the problem". The repetitious nature of following a trending feed unfold reinforces that each unique tweet comes from a real person behind each account, creating a sense of closeness with the users. The hosted conversation then becomes a shared vulnerable space for both the "protester" and those bearing witness to the protest.

Solinger et al. (2010) explores the importance of the first person in storytelling in the consciousness-raising practices of incarcerated women:

when storytellers boldly use the first person, they are sometimes claiming expertise and sometimes also claiming space for intimacy, even or especially in public. When an incarcerated woman begins a story with "I", she is, for one thing, explicitly inviting the listener/ reader to "know" her, to imagine her humanity. When she says "I" and the next incarcerated storyteller starts her story with "I," too, then the next, we begin to imagine a community of incarcerated women, speaking to us and also to each other... building community in the midst and against insanity of imprisonment. (p. 7) 
Though Solinger et al. (2010)'s research relates intimate in-person conversations, I believe that the online forum that mediated \#MeToo maintained very similar functions. The described purpose of "I" and "too" can be directly leveraged to make meaning of "me too". When asked about the significance of using "me too" as affirmative language, \#MeToo founder Tyrana Burke's perspective very much paralleled this logic: "on one side, it's a bold declarative statement that 'I'm not ashamed' and 'I'm not alone.' On the other side, it's a statement from survivor to survivor that says 'I see you, I hear you, I understand you and I'm here for you or I get it"' (Santiago \& Criss, 2017). These similarities point to the dominant assumption of this MRP that challenges the deterministic view of our relationship to technology; the medium is not necessarily the message, and mediation does not necessarily imply the message is lacking authenticity. Instead, \#MeToo is a compelling example of how technological mediation can be used as a tool for increasing connection to the lived experiences of others, resulting in collective identity building and solidarity.

As \#MeToo tweets gained prominence around the world, we witnessed the co-creation of collective survivor identity. Much like a single vote, the act of sharing one personal story may not have been what challenged our societal view of sexual violence and harassment against women; rather the mass reframing of those experiences sparked the ensuing conversations that would make their identity a politicized item of contentious conversation in the traditional media sphere and beyond. 


\section{The Adoption}

The Survivor Narrative: Viral Identity Politics and Political Empathy

It has been previously stated that \#MeToo was not the first viral moment of hashtag feminism that brought awareness to issues that disproportionately affect women. This begs the questions, what was it about \#MeToo that caused a global pause to renegotiate themes like the boundaries of consent, our relationship to battered women, and what constitutes harassment today. This section will consider feminist social-psychology of protest participation in order to address the importance of collective identity in both "recruitment" (Klandermans, 2014) and the adoption of the social movements messaging (Dunn, 2004). In order to assess this, I will evaluate the politicized collective survivor identity, how it was surface into traditional media, and the role of empathy in the adoption of a long-awaited counter-narrative that asserts women's accounts should be believed, they are not to be blamed, and perpetrators should be held accountable.

Olsen (2014) studied the evolution of \#BringBackOurGirls, the hashtag that gained virality after the Nigerian terrorist group Boko Haram kidnapped 276 girls from a secondary school. Olsen asserts that hashtag activism allows online communities to have an influence on agenda-setting in traditional media, where news media must not only be in active interaction with, but also reactive to viral social media conversations. This ability to move controversial conversations from the "margins" (Olsen, 2014) of public discourse to the mainstream demonstrates how social media and hashtag activism has begun to reconfigure the relationship between public discourse and dominant media narratives. Where mass media agenda-setting theory would attest that the media "tells people what to think about" (McCoombs \& Shaw, 1993), one could say that it is now the people who declare what is 
newsworthy in the media. Perhaps one of the most remarkable features of social media is that it is democratic in its ability to bypass the established bias of official sources and traditional media, giving a voice to ordinary citizens to transform the political and social make up of their country (Clark, 2012).

"Identity politics" is, in and of itself, a contentious topic of debate today. However, the practice of politicizing identities is not a new phenomenon; rather, it is a foundational device in the feminist toolkit that is increasingly valuable for understanding the social psychology of protest and activism (Klandermans, 2014). Identity politics refers "to organizing around the specific experience or perspective - or the collective identity, in sociological terms - of a given group as well as to organizing that has identity visibility as a goal” (Whittier, 2017, p. 3). A collective identity becomes politically relevant when individual actors who share either one or many specific identity qualifiers take part in political action on behalf of that group (Klandermans, 2014). In the world of digital activism, mediated collective identity and engagement have the capacity to accelerate viral hashtags and drive conversation across the online world and into traditional forms of news media, bringing that the topic of that emerging identity into political discourse (Gerbaudo \& Treré, 2015).

Klandermans (2014) theorized about identity processes in the context of protest participation, assessing how group identification creates a link between social identity and collective identity, and how this collective identity then becomes politicized. To return, briefly, to Bennett and Segerberg's (2012) logic of the emerging connective action, this framework suggest that the digital age has shifted the processes of participation by diminishing the need for collectivities that are grounded in our historic understanding of formal organizations. This points to the importance of self-categorization theory, which 
Klandermans (2014) defines as a theory that considers the contextual circumstances that bring an individual to act as a unique person, that is, display their personal identity, or act as a member of a specific group as it becomes salient, creating a sense of a collective without formal recruitment (Turner, 1999; Turner, Hogg, Oakes, Reicher, \& Wetherell, 1987). Klandermans (2014; Simon and Klandermans, 2001) maintain that when individuals become involved in protest on behalf of a group, the collective identity becomes politicized. They defined political collective identity participation as "a group members" willingness to engage, as a mindful and self-conscious collective (or representative thereof), in... a power struggle knowing that it is the wider, more inclusive societal context in which this struggle takes place" (p.323).

In the case of \#MeToo, the contextual circumstance, or "causality" (Klandermans, 2014), has been explored in the first section, which outlined the global context and the viral moment. It is vital then, to understand and make meaning from the collective identity that became most salient during the \#MeToo protest. I would contend that the power of this protest stems from the mass self-identification with the survivor identity, which is closely linked, but distinctly different from the victim identity. Tarana Burke herself noted that perhaps the most important thing the viral moment brought to fruition was the refocusing on survivors. The movement focused not on pointing blame, but rather highlighting the perseverance of women who continue to exist in a societal context that safeguards hierarchies of power that diminish their experiences with harassment and violence. Participation in the viral moment instead focused on bringing visibility to lived experiences of women, politicizing the collective survivor identity as it entered mainstream media discourse.

Dunn (2004) studies the self-identification, or "recruitment", in collective action, and 
argue that fundamental to this process is the resonance, or "framing", of the collective identity. The concept of framing, first developed by Erving Goffman (1974), allows us to study the "culturally determined definitions of reality that allow people to make sense of objects and events". Dunn (2004)'s work focuses on victim repertoires as participation in social movements, drawing meaning from the politics of empathy in the adoption of a protest messaging. She hypothesized the theory of "political empathy", a framework that compares the victim and survivor identity and the "feeling rules" associated with each narrative.

The theory of political empathy draws on social psychology, and is informed by Hochschild's (1979)'s feeling rules that dictate the appropriate emotional responses to victim's stories based of moral worthiness of blame, sympathy, contempt or admiration. Dunn (2004)'s framework is outlined below:

POLITICAL EMPATHY: EVALUATIONS, VICTIM TYPES, EMOTIONAL RESPONSES, RESONANCE, AND EXPRESSIONS

\begin{tabular}{|c|c|c|c|c|}
\hline $\begin{array}{l}\text { SOCIAL } \\
\text { EVALUATION } \\
\text { /AGENCY }\end{array}$ & VICTIM TYPE & $\begin{array}{l}\text { EMOTIONAL } \\
\text { RESPONSE }\end{array}$ & $\begin{array}{l}\text { CULTURAL } \\
\text { RESONANCE }\end{array}$ & $\begin{array}{l}\text { POLICY/COLLECTIVE } \\
\text { IDENTITY }\end{array}$ \\
\hline Negative/High & Precipitating & Blame, condemnation & $\begin{array}{l}\text { Patriarchy, } \\
\text { public/private split }\end{array}$ & $\begin{array}{l}\text { Denial of assistance } \\
\text { Shameful, individual } \\
\text { identification }\end{array}$ \\
\hline Positive/Low & Ideal & Sympathy & $\begin{array}{l}\text { Injustice, victims' } \\
\text { rights }\end{array}$ & $\begin{array}{l}\text { Help, assistance } \\
\text { Collective identification }\end{array}$ \\
\hline Negative/Low & Stigmatized & Pity, contempt & $\begin{array}{l}\text { Injustice, victims' } \\
\text { rights, medicalization }\end{array}$ & $\begin{array}{l}\text { Disempowering help } \\
\text { Dis-identification }\end{array}$ \\
\hline Positive/High & Heroic & Admiration & $\begin{array}{l}\text { Equal rights, self- } \\
\text { help }\end{array}$ & $\begin{array}{l}\text { Empowerment } \\
\text { Transformative } \\
\text { Identification }\end{array}$ \\
\hline
\end{tabular}

Figure 3. The framework of analysis for understanding the emotional responses of victims types. Adapted from The Politics of Empathy: Social Movements and Victim Repertoires by Dunn, J. L. (2004). Sociological Focus, 37(3), 235-250. https://doi.org/10.1080/00380237.2004.10571244 
This framework is insightful for understanding why millions of women self-identified with the movement, and why their stories were effective in challenging the persisting narratives that problematized victims in situations of assault. In a culture that values agency, autonomy, personal responsibility and presumption of innocence, the analysis of the victim identity is one that is unpredictable because the placement of blame is negotiable. Dunn's work suggests that the notion victimhood triggers a variation of emotions related to sympathy, pity or contempt. From the perspective of what Dunn (2004) calls "recruitment", this gives insight into why women may not have previously engaged in feminist activism - further, it is a view that could inform why some women choose not to identify as feminists at all. By selfidentifying as an oppressed group, the victim identity can be closely linked to assumed lack of agency and submission. The term "victim" often then takes on a pejorative connotation that suggests complacency. Dunn (2004) suggests that this identity becomes a "stigmatized victim": a person who, because she lacks agency, is negatively evaluated and who may evoke sympathy but who loses respect as a consequence and elicits, rather, pity and even a kind of contempt (p.244). Her evaluations using this framework suggests that when a politicized identity surfaces within these parameters, claims do not inspire lasting social change because repertoires are too easily contended or dismissed.

Alternatively, the framework suggests that the survivor identity is fundamentally different in that it inspires contrasting emotional triggers. The term "survivor" implies relative agency, which highlights the ways in which women resist and cope in order to survive. The survivor identity is a "positively evaluated construction of victimization that incorporates agency and inspires admiration, making it resonate with these cultural values and a transformative collective identity with which participants may more willingly identify" 
(Dunn, 2004, p.240). In this case, Dunn (2004) suggests that this identity is perceived as a "heroic victim", or rather "survivor": a collective that is positively socially evaluated and retain the agency lost to them in stigmatizing "pure victim" constructions. Theoretically, they have the potential to evoke admiration and trust. (p. 244)

The notions of agency and admiration are closely linked to empathy, which is a critical distinction when trying to rationalize why, in all moments of feminist protest, \#MeToo was effective in breaking through to the masses. In the case of \#MeToo, the very nature of the language "me too" communicates the notion of "it has happened to me as well, yet I am still here". This empowers the reframing the victim identity to that of a survivor, without the need to name their violator or any allegiance to a collective identity that formally declares themselves institutionally oppressed due to gender. When a protest frame surfaces into political discourse from this area of the framework, "collective identities move members from shame to pride and are constructed in public as well as within social movement realms, strategically and sometimes to great effect" (Dunn, 2004, p.238).

Though this framework does not consider the integration of technology as a factor, it is a useful tool for understanding \#MeToo. Much like revisiting other feminist tools like consciousness-raising and storytelling that predate the social media age, the theory of political empathy reinforces, once again, that combining both human elements like social psychology with emerging literature hat connects technological affordances of the digital age to activism creates a more rounded understanding of how these phenomena come to fruition. 


\section{Conclusion}

In an era defined by deep ideological divides, contentious politics, competing narratives and the affordances social media that provide each individual with a platform for articulating their perspectives, progress will not come from consensus. However, bringing contentious topics like women's universal experience with sexual violence and/or harassment into the public sphere is vital if we are to ensure that important, albeit uncomfortable, conversations enter the public sphere. Hashtag campaigns and online communities of discourse should be regarded as more than simply conversations that occur in isolation online, but rather as effective protest strategies that have the capacity to become important cultural moments.

The viral \#MeToo moment emphasizes the power of agency, storytelling and discourse in the digital age, and it suggests that there is a pressing need for further research at these intersections. Though an evaluation of the technological affordances of social media is crucial to understanding emerging protest logic, I would attest that it is also increasingly important to include literature grounded in human elements, regardless of the integration of technology. In the case of \#MeToo, the logical connection was to integrate feminist literature however, viral campaigns of the future will, inevitably, surface with latent problems that take issue with other areas of human rights. Overall, I would conclude that this analysis of \#MeToo discovered that as we continue to integrate technology into all aspects of our lives, we are not necessarily moving away from what makes us human in the digital world, but simply connecting us in new and meaningful ways. I maintain rhw belief that the future of communications and media studies should be reflective of this. The deterministic notion of an 
absolute distinction between "online" as "inauthentic" and "offline" as "real", is increasingly negligent. I would content that we should, instead, begin to emphasize emerging literature that regards the integration of technology as simply an evolution of existing human behavior.

It has been nearly a year since the world witnessed the viral \#MeToo moment, and yet, the movement continues to extend across the globe while maintaining the same vernacular in order to discuss sexual violence and harassment against women. As I write, I am learning about Chinese activists' desperate attempts to bypass China's censorship laws in order to ignite their own \#MeToo movement. They have managed to evade censors by using the rice and bunny emoji as they bravely share personal experiences, expressions of solidarity, and revolt against a government that refuses to allow them to protest in order to fight against violence and harassment. The words "rice bunny" are pronounced "mi tu" in Mandarin, phonetically mirroring \#MeToo (Yang, 2018). In the same day, a recent report alleges that one of the dominant voice in vilifying Harvey Weinstein has recently settled a dispute with a male minor, a revelation that challenges the integrity of the \#MeToo movement. This has sparked cries of hypocrisy in the movement, as well as a pointed opportunity to include the voices of men who have also experienced sexual trauma (Wong, 2018). The movement's founder, Tarana Burke, has responded with a twitter thread:

I've said repeatedly that the \#metooMVMT is for all of us, including these brave young men who are now coming forward. It will continue to be jarring when we hear the names of some of our faves connected to sexual violence unless we shift from talking about individuals

....and begin to talk about power. Sexual violence is about power and privilege. That doesn't change if the perpetrator is your favorite actress, activist or professor of any gender. And we won't shift the culture unless we get serious about shifting these false narratives.

My hope is that as more folks come forward, particularly men, that we prepare ourselves for some hard conversations about power and humanity and privilege and harm. This issue is less about crime $\&$ punishment and more about harm and harm reduction. 
People will use these recent news stories to try and discredit this movement - don't let that happen. This is what Movement is about. It's not a spectator sport. It is people generated. (Wong, 2018)

Perhaps this summarized one of the points that I have been attempting to make throughout this MRP: the power of activism in the digital age is not necessarily its ability to immediately change behavior offline, but rather to give a voice to the real-life injustices that a single person experiences in a way that can mobilizes the many. Most importantly, however, this process has the capacity for activists and feminists to co-create collective identities in a way that inserts their existence into political discourse while maintaining their humanity, inspiring empathy.

For better or for worse, we are at a pivotal point where we must accept that the way that we behave online directly contributes to the way that we make sense of the world and where we belong within in it as we build community, participate in political discourse and create our own identities through social media.

To conclude in a similar place to where I began: Vogue's September issue, recognized as the most important of the year, not only featured Beyonce, the first ever Black musician to grace the cover, but also, in an unprecedented moment, the magazine forfeited all creative agency to the musician, popstar and Black feminist activist. She used this opportunity to hire 23-year-old Tyler Mitchell, the first ever Black man to photograph a cover of the magazine in its 126-year publication history.

In the piece titled Beyonce in Her Own Words: Her Life, Her Body, Her Heritage, Knowles-Carter (2018) stated, “The beauty of social media is it's completely democratic. Everyone has a say. Everyone's voice counts, and everyone has a chance to paint the world 
from their own perspective". Perhaps more than ever, the personal is still political, and social media has given us a new set of effective tools to achieve social justice.

\section{Reference List}

Alyssa_Milano. (2016, Oct 15). If all women who have been sexually harassed or assaulted wrote 'me too' as a status, we might give people a sense of the magnitude of the problem [Tweet]. Retrieved from https://twitter.com/alyssa_milano/status/919659438700670976?lang=en

Benford, R. D., \& Snow, D. A. (2000). Framing Processes and Social Movements: An Overview and Assessment. Annual Review of Sociology, 26, 611-639. Retrieved from https://www.jstor.org/stable/223459

Bennett, W. L. (2012). The Personalization of Politics: Political Identity, Social Media, and Changing Patterns of Participation. The ANNALS of the American Academy of Political and Social Science, 644(1), 20-39. https://doi.org/10.1177/0002716212451428

Bennett, W. L., \& Segerberg, A. (2012). The logic of connective action. Information, Communication \& Society, 15(5), 739-768. https://doi.org/10.1080/1369118X.2012.670661

Black Lives Matter. (n.d.). Retrieved from https://blacklivesmatter.com

Borpatragohain, R. C. (2013). Safeguarding the Dignity of Women under the Criminal Law Amendment Act 2013-A Critical Analysis. Space and Culture, India, 1(2), 44-52.

Broomfield, M. (2017). 2 charts which show just how huge the Women's Marches against Trump were. Independent. Retrieved from http://www.independent.co.uk/news/world/americas/womens-march-anti-donaldtrump-womens-rights-largest-protest-demonstration-us-history-politicala7541081.html

Clark, R. (2016). "Hope in a hashtag": the discursive activism of \#WhyIStayed. Feminist Media Studies. Retrieved from http://www.tandfonline.com/doi/abs/10.1080/14680777.2016.1138235

Ditchburn, J., \& 2015. (2015). Women no longer a "curiosity" in cabinet. CBC News. Retrieved from https://www.cbc.ca/news/politics/canada-trudeau-liberal-government-cabinet$\underline{1.3304590}$ 
Dixon, K. (2014). Feminist online identity: analyzing the presence of hashtag feminism. Journal of Arts and Humanities, 3(7), 34-40. Retrieved from https://doaj.org/article/99bc56d0adf44fa8a511ae3197f46aa7

Dunn, J. L. (2004). The Politics of Empathy: Social Movements and Victim Repertoires. Sociological Focus, 37(3), 235-250. https://doi.org/10.1080/00380237.2004.10571244

Goffman, E. (1974). Frame analysis: an essay on the organization of experience. New York: Harper \& Row.

Fox, K., \& Diehm, J. (2017). \#MeToo's global moment: the anatomy of a viral campaign. Retrieved from https://www.cnn.com/2017/11/09/world/metoo-hashtag-global-movement/index.html

Gerbaudo, P. (2014). The persistence of collectivity in digital protest. Information, Communication \& Society, 17(2), 264-268. https://doi.org/10.1080/1369118X.2013.868504

Gerbaudo, P., \& Treré, E. (2015). In search of the 'we' of social media activism: introduction to the special issue on social media and protest identities. Information, Communication \& Society, 18(8), 865-871. https://doi.org/10.1080/1369118X.2015.1043319

Goodwin, J., \& Jasper, J. M. (2009). The Social Movements Reader: Cases and Concepts. John Wiley \& Sons.

Grant, T. (2018). A look at women's progress in Canada and around the world. The Globe and Mail. Retrieved from https://www.theglobeandmail.com/news/national/a-look-atwomens-progress-in-canada-and-around-theworld/article38198225/

Gunn, C. (2015). Hashtagging from the margins. In Tassie, K. E., \& Givens, S. M. B. (Eds). Women of Color and Social Media Multitasking: Blogs, Timelines, Feeds, and Community. Lexington Books.

Johnston, C., McDonald, H., O'Carroll, L., \& O'Carroll, L. (2015). Ireland becomes first country to legalize same-sex marriage by popular vote - as it happened. The Guardian. Retrieved from http://www.theguardian.com/global/live/2015/may/23/countingunderway-for-irelands-referendum-on-marriage-equality 
Knowles-Carter, B. (2018). Beyoncé September Issue in Her Own Words: Her Life, Her Body, Her Heritage. Vogue. Retrieved from https://www.vogue.com/article/beyonce-september-issue-2018

McCafferty, D. (2011). Activism Vs. Slacktivism. Communications of the ACM. 54(23), 1719. Retrieved from https://cacm.acm.org/magazines/2011/12/142536-activism-vs-slacktivism/fulltext

McDonald, H., Graham-Harrison, E., \& Baker, S. (2018). Ireland votes by landslide to legalize abortion. The Guardian. Retrieved from http://www.theguardian.com/world/2018/may/26/ireland-votes-by-landslide-tolegalise-abortion

Me Too Movement. (n.d.). Retrieved from www.metoomvmt.org

Milan, S. (2015). From social movements to cloud protesting: the evolution of collective identity. Information, Communication \& Society, 18(8), 887-900. https://doi.org/10.1080/1369118X.2015.104313

Miller, A. M. (2004). Sexuality, Violence against Women, and Human Rights: Women Make Demands and Ladies Get Protection. Health and Human Rights, 7(2), 16-47. https://doi.org/10.2307/4065347

Munro, E. (2013). Feminism: A fourth wave? Political Insight, 4(2), 22-25. https://doi.org/10.1111/2041-9066.12021

Norman, D. A. (2013). The design of everyday things (Revised and expanded edition). New York, New York: Basic Books. Retrieved from http://www.nixdell.com/classes/HCI-and-Design-Spring-2017/The-Design-ofEveryday-Things-Revised-and-Expanded-Edition.pdf

Papacharissi, Z. (2010). A Networked Self: Identity, Community, and Culture on Social Network Sites. Routledge.

Plott, M., \& Umansky, L. (2000). Making Sense of Women's Lives: An Introduction to Women's Studies. Rowman \& Littlefield.

Santiago, C., Criss, D. (2017) An activist, a little girl and the heartbreaking origin of "Me too". CNN. Retrieved from https://www.cnn.com/2017/10/17/us/me-too-tarana-burke-origin-trnd/index.html 
Simon, B., \& Klandermans, B. (2001). Towards a social psychological analysis of politicized collective identity: Conceptualization, antecedents, and consequences. American Psychologist. 56, 319-331.

Snow, D. A., Rochford, E. B., Worden, S. K., \& Benford, R. D. (1986). Frame Alignment Processes, Micromobilization, and Movement Participation. American Sociological Review, 51(4), 464. https://doi.org/10.2307/2095581

Solinger, R. (Ed.), Fox, M. (Ed.), Irani, K. (Ed.). (2008). Telling Stories to Change the World. New York: Routledge

Taylor, A. (2016). "Not My President”: Thousands March in Protest. The Atlantic. Retrieved from https://www.theatlantic.com/photo/2016/11/not-my-president-thousands-march-inprotest $/ 507248 /$

Time Magazine. (Ed.). (2002). Time: Person of the Year 75th Anniversary Celebration. Hachette Book Group.

Turner, J. C., Hogg, M. A., Oakes, P. J., Reicher, S. D., \& Wetherell, M. S. (1987). Rediscovering the social group: A self-categorization theory.

Turner, J. C. (1999). Some current issues in research on social identity and self-categorization theories. Social Identity (pp. 6-35)

Whittier, N. (2017) Identity Politics, Consciousness-Raising, and Visibility Politics. The Oxford Handbook of U.S. Women's Social Movement Activism. Retrieved from http://www.oxfordhandbooks.com/view/10.1093/oxfordhb/9780190204204.001.0001/ oxfordhb-9780190204204-e-20

Wong, J. (2018). \#MeToo movement reckons with alleged hypocrisy after Asia Argento accused of sexual abuse. $C B C$ News. Retrieved from https://www.cbc.ca/news/entertainment/asia-argento-1.4792101

Yang, Y. (2018) China's 'MeToo' movement evades censors with \#RiceBunny | Financial Times. Retrieved from https://www.ft.com/content/61903744-9540-11e8-b67b-b8205561c3fe 
